\title{
FEATURES OF INFECTED VERSUS UNINFECTED CHEMICAL PROFILES RELEASED FROM HUMAN EXUDATES
}

\author{
ILEANA-ANDREEA RATIU ${ }^{\mathrm{a}, \mathrm{b}^{*}}$, TOMASZ LIGOR ${ }^{\mathrm{a}}$, FERNANDA \\ MONEDEIRO ${ }^{\mathrm{a}, \mathrm{c}}$, HOSSAM AL-SUOD ${ }^{\mathrm{a}}$, VICTOR BOCOS-BINTINTAN ${ }^{\mathrm{d}}$, \\ JACEK SZELIGA ${ }^{\mathrm{e}}$, MAREK JACKOWSKI ${ }^{\mathrm{e}}$, BOGUSLAW BUSZEWSKI ${ }^{\mathrm{a}^{*}}$
}

\begin{abstract}
Detection of bacterial volatile metabolites produced by human pathogenic bacteria is gaining continuous interest in both scientific and medical fields. Solid-phase microextraction (SPME) is a sampling technique that gained increasing attention in the last years due to its simplicity to implement and sensitivity. Volatile organic compounds (VOCs) released in the headspace over exudates infected with different bacteria were investigated in this work. GC-MS was involved for analysis. The above mentioned VOCs resulted from bacterial metabolism and the afferent processes that occur inside the biological samples. However, we identified 14 compounds emitted by the infecting pathogens, which can be assumed as bacterial markers.
\end{abstract}

Keywords: bacterial markers, exudates, headspace profiles, diagnostic tool.

a Department of Environmental Chemistry and Bioanalytics, Faculty of Chemistry, Interdisciplinary Centre of Modern Technologies, Nicolaus Copernicus University,7 Gagarina Str., 87-100 Torun, Poland

b Faculty of Chemistry and Chemical Engineering, Babeş-Bolyai University, 11 Arany Janos, RO-400028, Cluj-Napoca, Romania

c Department of Chemistry, Faculty of Philosophy, Science and Letters of Ribeirão Preto, University of São Paulo, CEP 14040-901 Ribeirão Preto, Brazil

d Faculty of Environmental Science and Engineering, Babeş-Bolyai University, 30 Fântânele ,RO-400294 Cluj-Napoca, Romania

e Dept. of General, Gastroenterologic and Oncologic Surgery Collegium Medicum, Nicolaus Copernicus University, Torun, Poland

*Corresponding authors email: busz@chem.umk.pl; andreea_ratiu84@yahoo.com 
ILEANA-ANDREEA RATIU, TOMASZ LIGOR, FERNANDA MONEDEIRO, HOSSAM AL-SUOD, VICTOR BOCOS-BINTINTAN, JACEK SZELIGA, MAREK JACKOWSKI, BOGUSLAW BUSZEWSKI

\section{INTRODUCTION}

Typical microbiological methods for bacteria identification are usually expensive and time consuming. This whole necessary procedure is a great burden for the health care system. Therefore, having the possibility of identifying bacterial biomarkers directly from clinical samples may offer a valuable opportunity for developing rapid and inexpensive diagnostic tools $[1,2]$. An in situ methodology that is non-invasive, rapid and sensitive will definitely facilitate timely and effective diagnosis which is highly desired. In vitro studies have been carried out in attempt to create bacterial fingerprint data bases for relevant human pathogens $[3,4]$. VOCs emitted by human biological samples (e.g. breath, urine, tissue) were analysed and proposed to be used as a diagnostic tool for various diseases or for bacterial infection, because it does not require invasive procedures, reagents usage or complex sample preparation methods $[5,6]$. SPME is widely used for VOCs analysis since it is a simple and effective sampling technique, combining the sampling, selective isolation, and pre-concentration in a single step. Gas chromatography coupled with mass spectrometry (GC-MS) provides detailed analytical information and identifies the analyses with the highest certainty, when compared to other techniques. [7].

Different other analytical techniques, for example SIFT-MS (selected ion flow tube-mass spectrometry), PTR-MS (proton transfer reaction mass spectrometry), SESI-MS (secondary electrospray ionization mass spectrometry) were involved in direct measurements of bacterial biomarkers [8]. Ion mobility spectrometry (IMS), and multi-capillary GC columns coupled to an ion mobility spectrometer (MCC-IMS) were used for detection of pathogenic bacteria by sniffing their characteristic emitted volatiles $[9,10]$. Sensors and e-noses can be used for detection and monitoring of target components, but as standalone instrumentation they do not have have the potential for chemical identification of complex VOCs profiles [11-14]. Identification and classification of bacteria can be achieved by MALDI MS (matrix-assisted laser desorption and ionization coupled with mass spectrometry) [15]. In spite of its capabilities, MALDI MS does not detect VOCs and is a more expensive instrumentation compared with GC-MS.

The aim of this research was to analyse samples of infected exudates and to identify the presence of the bacterial colonization and pathogens themselves. The advantage of this approach consists in the simplicity of the method and in getting closer with real scenario of clinical samples. To detect pathogen-specific signals in the context of an infection remains a challenge, however, 14 compounds were assumed as bacterial markers in this study. 


\section{RESULTS AND DISCUSSIONS}

Uninfected samples were used as controls. The identity of each component in chromatograms was assigned using the NIST data base. The peaks with a Match Factor value $>850$ were only considered. The VOCs emitted by infected samples resulted in 46 compounds.

Table 1 presents the identified substances coming from the 15 patients $(P)$, together with the infecting pathogen. The identity of infecting pathogens was provided by the behind microbiological clinical trials realized in the hospital. Finally, 8 bacterial species named: Escherichia coli (E. coli), Enteroccus faecalis (E. faecalis), Citrobacter freundii (C. freundii), Staphylococcus aureus (S. aureus), Proteus mirabilis ( $P$. mirabilis), Pseudomonas aeruginosa (P. aeruginosa), Morganella morganii ( $M$. morganii) and Stenotrophomonas maltophilia (S. maltophilia) were identified as infecting pathogens of investigated samples. We assume that some of compounds presented in Table 1 are metabolism products of bacteria, while others are degradation products of mammalian and bacterial cells. The compounds identified in infected samples and confirmed to be similar with those detected in headspace of in vitro cultivated bacteria (confirmation with literature, reference presented in Table 1) were considered bacterial markers and they are bold highlighted. By visual inspection of chromatograms, we noticed that samples infected with $P$. mirabilis presented higher peaks intensities compared with others. Less intensive peaks were observed for $P 2,3$ and 6 . Chromatograms of samples coming from $P$ 7, 8, 9 and 10 present more components compared with others. Generaly, highest signals were observed for indole, dimethyl disulfide, dimethyl trisulfide and benzoic acid ethyl ester. Uninfected profiles were significantly different of infected profiles. The presence of markers like indole, volatile sulfur components, butanoic acid, acetic acid and alcohols (1-butanol, 3methyl, phenylethyl alcohol) was not observed in the blanks.

\section{Bacterial markers emitted from investigated strains}

Biological samples, like exudates, are complex mixtures containing huge number of substances. Phospholipids, proteins, amino acids, fatty acids, etc are indispensable to living cells. Microorganisms, can degrade organic material according with their metabolisms, resulting in a variety of VOCs. When we talk about volatiles emitted from infected clinical samples, they can be bacterial volatile metabolites, also they may reflect the pathogeninduced host responses, [21], endogenous enzymes produced compounds [22], as well as putrefaction products. Comparing the components from Table 1 with those detected from cultivated bacteria, it was noticed that the profiles of cultivated bacteria and samples collected from human patients are 
different. However, 14 compounds observed in clinical samples were common with those produced by bacteria grown in vitro. We assume that they were produced by pathogens, and can be considered bacterial markers. We present them in Figure 1, with the connection between producing bacteria and patient in which were detected.

Table 1. Compounds detected in infected and uninfected samples

\begin{tabular}{|c|c|c|c|}
\hline $\begin{array}{c}\text { Patient } \\
\text { ID }\end{array}$ & Detected components & $\begin{array}{l}\text { Infecting } \\
\text { pathogen }\end{array}$ & Ref \\
\hline $\begin{array}{c}\text { Patient } \\
1\end{array}$ & $\begin{array}{l}\text { 1-pentanol, 2-nonanone, acetoin, benzyl alcohol, decane, dimethyl } \\
\text { trisulfide, dimethyl disulfide, ethanol, indole, limonene, octanal, } \\
\text { phenylethyl alcohol }\end{array}$ & E. coli & 4 \\
\hline \begin{tabular}{|c|} 
Patient \\
2
\end{tabular} & $\begin{array}{l}\text { 1-pentanol, acetoin, benzaldehyde, benzyl alcohol, biphenyl, } \\
\text { dodecanal, ethanol, hexanal, limonene, undecane. }\end{array}$ & $\begin{array}{l}\text { E. coli }+E . \\
\text { faecalis }\end{array}$ & $\begin{array}{l}4, \\
16\end{array}$ \\
\hline \begin{tabular}{c|} 
Patient \\
3
\end{tabular} & $\begin{array}{l}\text { 1-octanol, 1-pentanol, acetoin, benzoic acid ethyl ester, biphenyl, } \\
\text { decane, hexanal. }\end{array}$ & E. coli & 4 \\
\hline $\begin{array}{c}\text { Patient } \\
4\end{array}$ & $\begin{array}{l}\text { 1-butanol, 1-octanol, 1-pentanol, 2-methyl-butanoic acid, 3-methyl } \\
\text { butanoic acid, benzeneacetaldehyde, benzoic acid ethyl ester, } \\
\text { benzyl alcohol, biphenyl, butanoic acid, dimethyl disulfide, } \\
\text { hexanal, indole, methyl-thiolacetate, phenol, tetradecane. }\end{array}$ & $\begin{array}{l}\text { C. freundii + } \\
\text { S. aureus }\end{array}$ & $\begin{array}{l}17 \\
18\end{array}$ \\
\hline $\begin{array}{c}\text { Patient } \\
5\end{array}$ & $\begin{array}{l}\text { 1-hexanol, 1-nonanol, 1-octanol, 2-methyl-butanoic acid, 3-methyl- } \\
\text { 1-butanol, 3-methyl-butanoic acid, acetic acid, acetophenone, } \\
\text { benzeneacetaldehyde, benzoic acid ethyl ester, benzyl alcohol, } \\
\text { biphenyl, dimethyl disulfide, dimethyl trisulfide, dodecane, } \\
\text { indole, limonene, naphthalene, tetradecane. }\end{array}$ & $\begin{array}{l}P . \text { mirabilis+ } \\
P . \\
\text { aeruginosa }\end{array}$ & $\begin{array}{l}9 \\
19\end{array}$ \\
\hline \begin{tabular}{|c|} 
Patient \\
6
\end{tabular} & $\begin{array}{l}\text { acetic acid, benzaldehyde, benzoic acid ethyl ester, benzyl alcohol, } \\
\text { biphenyl, naphthalene, nonanal, tetradecane, toluene. }\end{array}$ & $\begin{array}{l}P . \\
\text { aeruginosa }\end{array}$ & 20 \\
\hline \begin{tabular}{|l|} 
Patient \\
7
\end{tabular} & $\begin{array}{l}\text { 1-hexanol, 3-methyl-1-butanol, acetophenone, dimethyl disulfide, } \\
\text { dimethyl tetrasulfide, dimethyl trisulfide, dodecane, ethanol, } \\
\text { hexanal, indole, naphthalene, octanal, phenol, phenylethyl alcohol. }\end{array}$ & P. mirabilis & $\begin{array}{l}9, \\
19\end{array}$ \\
\hline $\begin{array}{l}\text { Patient } \\
8\end{array}$ & $\begin{array}{l}\text { 1-hexanol, 2-nonanone, 2-tridecanone, 3-methyl-1-butanol, benzoic } \\
\text { acid ethyl ester, biphenyl, dimethyl disulfide, dimethyl tetrasulfide, } \\
\text { dimethyl trisulfide, dodecane, ethanol, hexanal, indole, limonene, } \\
\text { naphthalene, phenol, tetradecane, }\end{array}$ & $\begin{array}{l}\text { M. morganii } \\
+\quad S . \\
\text { maltophilia }\end{array}$ & $\begin{array}{l}15 \\
19\end{array}$ \\
\hline $\begin{array}{l}\text { Patient } \\
9\end{array}$ & $\begin{array}{l}\text { 1-octanol, 2-methyl- butanoic acid, 2-nonanone, 3-methyl-1- } \\
\text { butanol, 3-methyl-butanoic acid, acetophenone, benzyl alcohol, } \\
\text { butanoic acid, chloroaniline, dimethyl disulfide, dimethyl } \\
\text { trisulfide, dodecane, ethanol, indole, octanoic acid, pentanoic acid, } \\
\text { phenol, phenylethyl alcohol, tetradecane. }\end{array}$ & P. mirabilis & 9,19 \\
\hline $\begin{array}{l}\text { Patient } \\
10\end{array}$ & $\begin{array}{l}\text { 1-hexanol, 1-nonanol, 1-octanol, 1-pentanol, 2-methyl-butanoic } \\
\text { acid, 2-nonanone, 3-methyl-1-butanol, 3-methyl-butanoic acid, } \\
\text { acetophenone, butanoic acid, dimethyl tetrasulfide, dimethyl } \\
\text { disulfide, dimethyl trisulfide, dodecane, indole, nonanal, pentanoic } \\
\text { acid, phenol, phenylethyl alcohol,tetradecane. }\end{array}$ & P. mirabilis & 9,19 \\
\hline \begin{tabular}{|l|} 
Patient \\
11
\end{tabular} & $\begin{array}{l}\text { 1-decene, 1-dodecene, 4-methyl-octane, dodecane, eicosane, } \\
\text { limonene, octadecanal, octane, pentadecane, undecane. }\end{array}$ & Uninfected & \\
\hline \begin{tabular}{|l|} 
Patient \\
12
\end{tabular} & $\begin{array}{l}\text { 1-decene, 1-dodecene, 4-methyl-decane, 4-methyl-octane, decane, } \\
\text { dodecane, eicosane, octane, propofol, tetradecane, undecane. }\end{array}$ & Uninfected & \\
\hline \begin{tabular}{|l|} 
Patient \\
13
\end{tabular} & $\begin{array}{l}\text { 1-decene, 1-dodecene, 2-methyl-dodecane, decane, dodecane, } \\
\text { eicosane, limonene, octane, propofol, tetradecane, undecane. }\end{array}$ & Uninfected & \\
\hline \begin{tabular}{|l|} 
Patient \\
14
\end{tabular} & $\begin{array}{l}\text { 1-decene, 1-dodecene, 4-methyl-decane, 4-methyl-octane, decane, } \\
\text { dodecane, eicosane, octane, propofol, tetradecane, undecane. }\end{array}$ & Uninfected & \\
\hline \begin{tabular}{l|} 
Patient \\
15
\end{tabular} & $\begin{array}{l}\text { 1-decene, 1-dodecene, 4-methyl-octane, decane, dodecane, } \\
\text { eicosane, limonene, octane, propofol, tetradecane, undecane. }\end{array}$ & Uninfected & \\
\hline
\end{tabular}


Figure 1 denotes discrimination among some strains as well. For example, E. coli, having as markers acetoin, 1-pentanol, ethanol, indole and hexanal, could not be confused with $P$. mirabilis or $M$. morganii, which are represented by 1-octanol, phenylethyl alcohol, 3-methyl-1-butanol, dimethyl trisulfide and phenol, although if all three have dimethyl disulfide as a common metabolite. In the same time $E$. coli can be confused with $E$. faecalis, because the first one include the markers generated by the second one, however, never the opposite due mostly to the indole occurrence. Moreover, considering that the metabolites emitted by each bacteria are coming together in a particular combination of components like a fingerprint, statistical approaches were used in order to check the differences between profiles emitted by samples infected with different pathogens and controls.

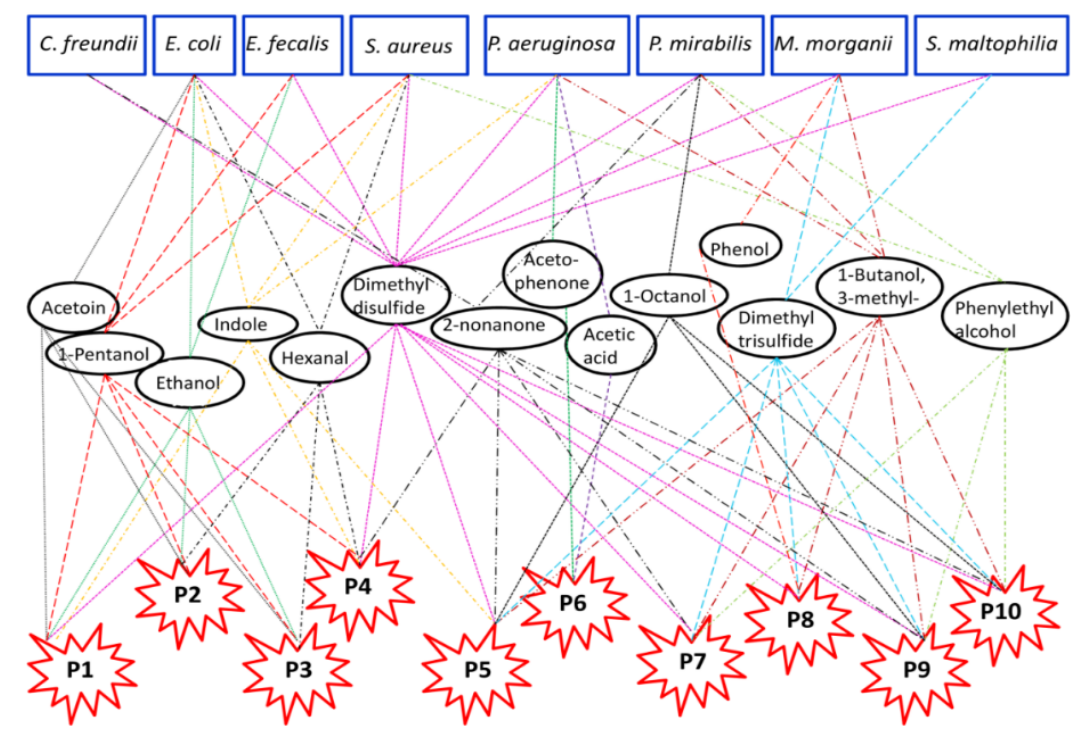

Figure 1. Detected bacterial markers and the links between infecting pathogens and the donor patients.

\section{Discrimination between infected and uninfected profiles}

A dendrogram using Ward linkage (created in IBM SPSS Statistics 21) is presented in Figure 2. The formation of two separated categories of clusters: coming from infected and uninfected patients respectively was observed. Infected group is presented again different cluster modeling, according with infecting pathogens. Thus, separated clusters were obtained for P1 to P3 infected or coinfected with E. Coli, while the sample infected with 
$P$. Aeruginosa clustered close with the previously mentioned three. All the samples infected or coinfected with $P$. Mirabilis clustered nearby and separately the samples coinfected with $C$. freundii $+S$. aureus and $M$. morganii $+S$. maltophilia were positioned. In contrast with in vitro cultivated samples, in case of biological samples, the grouping of clusters can be sometimes disturbed, for some reasons listed below. Microbial density is difficult to control in a biological sample. If the number of bacterial cell is too high, the metabolic pathways can be influenced, due to intra-specific interactions. If samples are infected with more bacterial strains, ecological interactions can occur. Considering that our exudates samples were collected from postoperative patients, previously cured with antibiotics, under anaesthesia or treated with bactericide or bacteriostatic agents, is possible that all this agents together can change the bacterial metabolism, resulting in some new or atypical compounds.

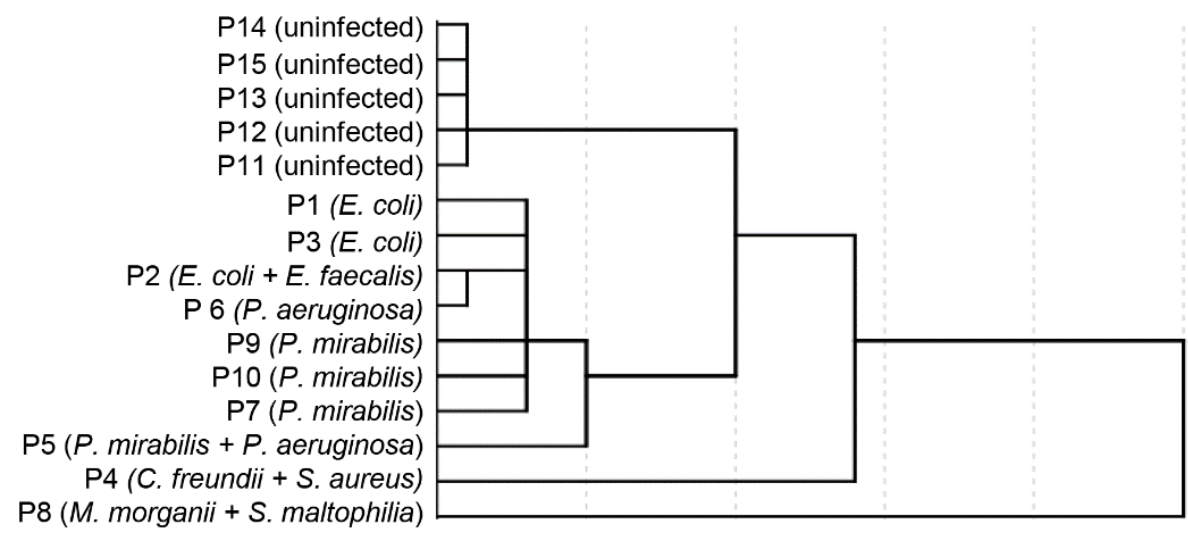

Figure 2. Discrimination between infected and uninfected group enrolled in the study, as well as between patients infected with different pathogens.

\section{Emitted VOCs as a diagnostic tool for bacterial infections}

The using of VOCs emitted by bacteria in attempt to create screening tools which has the ability to confirm or deny the presence of a bacterial infection, or moreover to predict the infecting pathogen identity is a tempting and bright perspective. ROC curves (receiver-operating characteristic) offer the possibility to test between two states of health and are a suitable choice to test the performance of analytical and clinical application. This model can be used for prediction of a diagnostic in absence of knowledge of true disease 
status. Thus ROC curves were used to test the diagnostic ability based on detected VOCs. We tested four types of infected profiles (those with E. coli, with $P$. mirabilis, with $P$. aeruginosa and all the co-infected samples together) versus uninfected profiles. A binary algorithm classifier was used, where the volatiles coming from infected samples were assumed as positive, while those received from uninfected samples as negative. The obtained results show that the area under the receiver-operating characteristic ( $95 \%$ probability interval) was 0.830 in case of samples infected with $E$. coli, 0.907 for samples infected with $P$. mirabilis, and 0.856 for those infected with $P$. aeruginosa. The AUC in case of co-infected samples was 0.875 , and 0.522 for uninfected samples, as seen in Figure 3. The positioning of control value (of uninfected samples) in the middle of the range between 0 and 1 , confirm that the diagnosis predictability worked correct, once 0.522 value predict nothing; giving the same accuracy like when you roll up a coin. However, this finding indicates a good predictability of infection (more that $80 \%$ ) and the possibility to apply this methodology as a new diagnostic tool of bacterial infection.

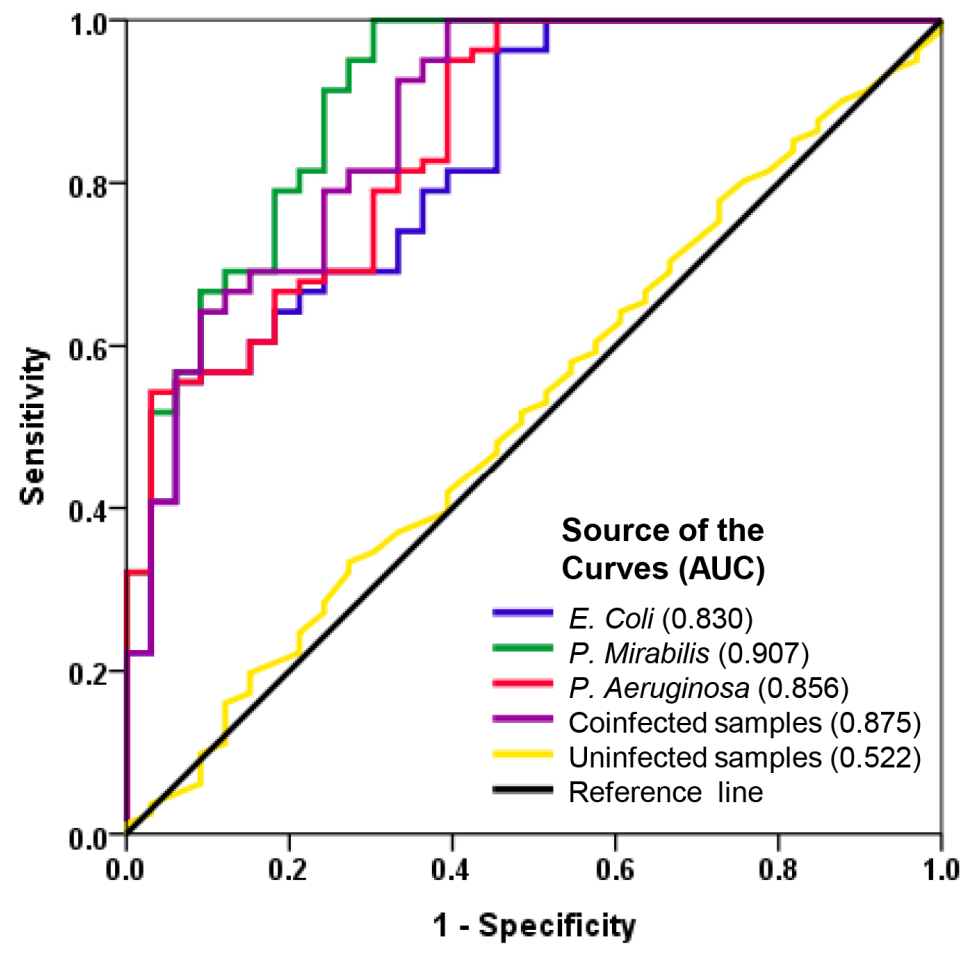

Figure 3. ROC presenting the ability of VOCs to predict bacterial infections. 
ILEANA-ANDREEA RATIU, TOMASZ LIGOR, FERNANDA MONEDEIRO, HOSSAM AL-SUOD, VICTOR BOCOS-BINTINTAN, JACEK SZELIGA, MAREK JACKOWSKI, BOGUSLAW BUSZEWSKI

\section{CONCLUSIONS}

The possibility of using volatile metabolites emitted by bacteria as a diagnostic tool is a promising perspective. The potential of discrimination between volatiles emitted by infected and uninfected exudates was proven through this study; infected samples presented a different cluster modelling, according with the infecting pathogens. Each bacterial strain relieved a characteristic fingerprint of components, which was reflected in different combinations of VOCs, as highlighted in Table 1. A good predictability of diagnosis accuracy, (between $83 \%$ and $90 \%$ ) for infected patients, was achieved when ROC curves were generated. Nevertheless, additional fast and on-site spectrometry techniques can be used for the detection of biomarker compounds specific to bacteria, once they are known and confirmed by GCMS. Starting from the key biomarkers detected, instrumentation used for fast screening of bacterial infection from various matrixes can be develop.

\section{EXPERIMENTAL SECTION}

A mass spectrometer Agilent 5975 Inert XL MSD coupled with a gas chromatograph Agilent 6890 N (Agilent, Waldbronn, Germany) with splitsplitless injector were used for analysis. The operating conditions and characteristics for the GC/MS system are presented in Table 2. The chromatographic data achisition was performed by means of Chemstation software package (Agilent). The mass spectrum library NIST 2005 (Gaithersburg, USA) was used for identification. PDMS/DVB coated fiber was used for sampling. Screw top headspace glass vials $(20 \mathrm{~mL})$ with silicon/ PTFE septa and caps were provided by Supelco.

Table 2 Operating conditions and characteristics for the GC/MS system

\begin{tabular}{|c|c|c|}
\hline $\begin{array}{c}\text { SPME } \\
\text { desorption }\end{array}$ & $0 \mathrm{~N}$ & $\begin{array}{c}\text { Agilent-5975 Mass Selective } \\
\text { Detector }\end{array}$ \\
\hline $\begin{array}{l}\text { Desorption flow: } \\
35 \mathrm{~cm}^{3} \mathrm{~min}^{-1} \\
\text { Desorption } \\
\text { temperature: } \\
240^{\circ} \mathrm{C} \\
\text { Desorption time: } 2 \\
\text { min }\end{array}$ & $\begin{array}{l}\text { Column: } 30 \mathrm{~m} \times 0.25 \mathrm{~mm} \times 0.25 \mu \mathrm{m} \\
\text { RTX-5MS } \\
\text { Velocity : He @ } 1.1 \mathrm{~cm}^{3} \mathrm{~min}^{-1} \\
\text { Initial oven temperature: } 40^{\circ} \mathrm{C}(5 \mathrm{~min}) \\
\text { Initial hold time: } 5 \mathrm{~min} \\
\text { Oven temperature program: } 10^{\circ} \mathrm{C} \mathrm{min}^{-1} \\
\text { to } 300^{\circ} \mathrm{C} \text { - hold for } 5 \mathrm{~min}\end{array}$ & $\begin{array}{l}\text { Scan type: Full Scan } \\
\text { Mass range: } 30 \text { to } 300 \mathrm{~m} / \mathrm{z} \\
\text { lonization type: EI } 70 \mathrm{eV} \\
\text { Scan rate: } 3.4 \text { scan } / \mathrm{s} \\
\text { lon source temperature: } 280^{\circ} \mathrm{C} \\
\text { Transfer line temperature: } 250^{\circ} \mathrm{C} \\
\text { Total run time: } 33 \mathrm{~min}\end{array}$ \\
\hline
\end{tabular}


All biological infected samples were collected from surgical wounds, under aseptic conditions in the Department of General, Gastroenterological and Oncological Surgery of Collegium Medicum of Nicolaus Copernicus University, according with the agreement KB 730/2016, signed on 13 December 2016 by Ethical Committee Collegium Medicum, in Bydgoszcz. A number of 10 volunteers, diagnosed with surgical-site infection based on typical clinical symptoms were included into the study. Apart of those, 5 more patients undergoing surgery, without bacterial infection, were enrolled into the study to collect the control samples. Local anesthesia with 1-2\% lignocaine (Lignocaine hydrochloride) infiltration was used. Prior to sample collection, water solution of "Octanisept" were used for wound cleaning.

When samples were collected, the identity of infecting pathogens was unknown. At the same time a classic wound smear using a microbiological swab was collected and transferred for routine identification (classical methods of bacteriological diagnostics). For the chromatographic analyses, the exudates were collected in sterile container, transported into the laboratory and analyzed in maximum 4 hours. In the laboratory each sample was transferred to in a $20 \mathrm{~mL}$ glass vials crimped with silicon septa and incubated at $37^{\circ} \mathrm{C}$ for $30 \mathrm{~min}$. In the next step, the SPME was inserted into the glass vial over sample, through the septum, for a period of $45 \mathrm{~min}$. After extraction the volatiles were desorbed in hot GC injector in splitless mode for 2 min.

\section{ACKNOWLEDGMENTS}

The financial resources for conducting the scientific research was obtained under the research grant for young researchers from abroad awarded by the Rector of the Nicolaus Copernicus University pursuant to Order no. MNZ/01/1029.

\section{REFERENCES}

1. Y. Kim, K. Park, K. Lee, Y.J. Park. Annals of Laboratory Medicine, 2015, 35, 422.

2. I.A. Ratiu, T. Ligor, V. Bocos-Bintintan, J. Szeliga, K. Machała, M. Jackowski, B. Buszewski, Journal of Breath Research 2019, 13, 026003 https://doi.org/10.1088/1752-7163/aaf708.

3. B. Buszewski, I.A. Ratiu, M. Milanowski, P. Pomastowski, T. Ligor, Journal of Breath Research, 2018, 12, 027105. 
ILEANA-ANDREEA RATIU, TOMASZ LIGOR, FERNANDA MONEDEIRO, HOSSAM AL-SUOD, VICTOR BOCOS-BINTINTAN, JACEK SZELIGA, MAREK JACKOWSKI, BOGUSLAW BUSZEWSKI

4. I.A. Ratiu, V. Bocoş-Bintintan, M. Turner, V. Moll, C.L.P. Thomas, Current Analitical Chemistry, 2014, 10, 488.

5. D. Chan, C. Leggett, K. Wang, World Journal of Gastroenterology, 2016, 2, 1639.

6. C.S.J. Probert, I. Ahmed, T. Khalid, E. Johnson, S. Smith, N. Ratcliffe, Journal of Gastrointestinal and Liver Diseases, 2009, 18, 337.

7. I.A. Ratiu, T. Ligor, V. Bocos-Bintintan, H. Al-Suod, T. Kowalkowski, K. Rafińska, B. Buszewski, Journal of Breath Research, 2017, 11, 036012.

8. I.A. Ratiu, T. Ligor, V. Bocos-Bintintan, B. Buszewski, Bioanalysis, 2017, 9, 1069.

9. M. Jünger, W. Vautz, M. Kuhns, L. Hofmann, S. Ulbricht, J.I. Baumbach, M. Quintel, T. Perl, Applied Microbiology and Biotechnology. 2012, 93:2603.

10. I.A. Ratiu, V. Bocos-Bintintan, A. Patrut, V. Moll, M. Turner, C.L.P. Thomas, Analitica Chimica Acta, 2017, 982, 209.

11. R. Huo, A. Agapiou, V. Bocos-Bintintan, L.J. Brown, C. Burns, C.S. Creaser, N.A. Devenport, B. Gao-Lau, C. Guallar-Hoyas, L. Hildebrand, A. Malkar, H.J. Martin, V.H. Moll, P. Patel, I.A. Ratiu, J.C. Reynolds, S. Sielemann, R. Slodzynski, M. Statheropoulos, M.A. Turner, W. Vautz; V.E. Wright, C.L.P. Thomas, Journal of Breath Research, 2011, 5, 046006.

12. V. Bocos-Bintintan, A. Smolenschi, I.A. Ratiu, Studia UBB Chemia, 2016, LXI, 203.

13. G.B. Ghira, I.A. Ratiu, V. Bocoş-Binţinţan, Environmental Engineering and Management Journal, 2013, 12 (2), 251.

14. V. Moll, V. Bocoş-Binţinţan, I.A. Ratiu, D. Ruszkiewicz, C.L.P. Thomas, Analyst, 2012, 137(6), 1458

15. J.L. Narayana, J. Gopal, H.F. Wu, Analyst, 2012, 137, 3372.

16. R.S.M. Thorn, d.m. Reynold, J. Greenman, Journal of Microbiological Methods, 2011, 84, 258.

17. G. Preti, E. Thaler, C.W. Hanson, M. Troy, J. Eades, A.J. Gelperin, Journal of Chromatography B, 2009, 877, 2011.

18. A.b. DeMilo, C.J. Lee, D.S. Moreno, A.J. Martinez, Journal of Agricultural and Food Chemistry, 1996, 44, 607.

19. E. Tait, J.D. Perry, S.P. Stanforth, J.R. Dean, Trends in Analitical Chemistry, 2014, 53, 117.

20. R.a. Quinn, K. Whiteson, Y.W. Lim, J. Zhao, D. Conrad, J.J.L. Puma, F. Rohwer, S. Widder. Biofilms Microbiomes, 2017, 2, 11.

21. S. Sethi, R. Nanda, T. Chakraborty, Clinical Microbiology Review, 2013, 26, 462.

22. S. Paczkowski, S. Schütz, Applied Microbiology \& Biotechnology, 2011, 91, 917. 